\title{
CONTROL OF SEED BORNE FUNGI ON TOMATO SEEDS AND THEIR MANAGEMENT BY BOTANICAL EXTRACTS
}

\author{
Imam Mehedi, Afia Sultana* and Md. Amanut Ullah Raju
}

Department of Plant Pathology, Faculty of Agriculture, Bangladesh Agricultural University, Mymensingh-2202, Bangladesh

*Corresponding author: Afia Sultana; E-mail: af.sultana87@gmail.com

\section{ARTICLE INFO}

ABSTRACT

Received

02.10.2016

Accepted

13.12.2016

Online

18 December 2016

Key words

Seed borne fungi, Tomato,

Botanical extract, Control
Seed health test was done in laboratory to determine the status of seed borne fungi on seeds of five tomato (Lycopersicon esculentum) varieties viz. Manik, Ratan, Roma VF, Kopotakkho and Monirumpuri and their possible control by using plant extracts. A total of 4 genera of 3 species of fungi were recorded where Fusarium oxysporum was the most prevalent and predominant seed borne fungus (25.60\%). Other three fungal species are Aspergillus sp. of Aspergillus flavus (21.70\%) and Aspergillus niger (11.11\%) and Cladosporium sp. (13.49\%). Tomato seeds were treated with different plant leaf extracts namely Mahogany, Mehendi and Allamanda with different doses viz. 1:1, 1:2 and 1:3 to control the seed borne fungi. In treated seeds, germination was ranged from $72-82 \%$ which was $68 \%$ in controlled condition. Among the doses of three botanicals, Mahogany, Mehendi and Allamonda extract @ $(1: 1 \mathrm{w} / \mathrm{v})$ showed significant performance in controlling seed borne fungi and germination of tomato seeds. Among the three botanicals, Mahogany @ $(1: 1 \mathrm{w} / \mathrm{v})$ was found the best treatment regarding percent reduction of seed borne infection.

To cite this article: Mehedi I, A Sultana and MAU Raju, 2016. Control of seed borne fungi on tomato seeds and their management by botanical extracts. Res. Agric. Livest., Fish., 3 (3): 403-410.

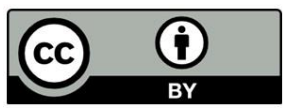

This is an open access article licensed under the terms of the Creative Commons Attribution 4.0 International License

www.agroaid-bd.org/ralf, E-mail: editor.ralf@gmail.com 


\section{INTRODUCTION}

Tomato (Lycopersicon esculentum) belongs to the genus Lycopersicon is considered as the most important food crops in Bangladesh. Present world production is about 100 million tones fresh fruit produced on 3.7 million hectares (www.growtomatoes.com). The yield of tomato is very low in Bangladesh compared to other countries of the world. In Bangladesh, 251.00 tons of tomato was produced in 2013 which is $0.2 \%$ of the world share (www.factfish.com). The major constraints of tomato production in Bangladesh are pests, diseases, weeds, lack of quality seeds, postharvest losses, environmental factors etc. Among these constrains, seed borne disease is very crucial. The seed borne pathogens mostly fungi play a vital role in disease development which harms the seed both quantity and quality during pre-emergence to harvest. The seed borne fungal pathogen may because seeds fail to germination or transmit disease from seed to seedling and/or from seedling to growing plant (Islam and Borthakur, 2012). Fungal pathogens may be externally or internally seedborne, extra or intra-embryal or associated with the seeds as contaminants (Singh and Mathur, 2004). Management of plant diseases is important for most crops and it is particularly critical for the production of high quality seed. The control of seed borne pathogens is the first step in any agricultural crop production and protection programmed. Attempts have been made to reduce seed borne infection by chemical treatment of the seeds and some successes have been reported. Though, chemical controls of seed borne pathogens have been very successful, chemical pesticides have the additional potential disadvantages of accumulation in the ecosystem and of induction of pesticide resistance in pathogens (Okigbo, 2004). There is also the problem of lack of expertise in the safe handling of chemical pesticides amongst most of the farmers. Moreover, the costly chemicals are being imported from abroad and farmers have to purchase with high price. In recent years, much attention has been given to nonchemical systems for seed treatment to protect seeds against many plant pathogens (Nwachukwu and Umechuruba, 2001). Eventually a big amount of foreign currency goes out of the country every year due to control of the pathogen. It is therefore, necessary to search for seed quality control measures that are cost effective, ecologically sound and environmentally safe to eliminate or reduce incidence of pathogens of economic importance to increase both seed germination and yield of plant crops. Antifungal activity of different plant extracts have been reported earlier by several investigators against a number of plant pathogens (Hassan et al., 2005; Yang and Clausa, 2007). However, information on management of seed borne fungal pathogens using botanicals on the major vegetable crops especially on tomato is lacking in Bangladesh.

Therefore, there is a great need for recording fungi associated with tomato seeds through easy, quick, reliable and economic seed health testing techniques for proper detection of seed borne pathogens in the crop. The botanicals are easily available and low cost compared to the chemical fungicides. In the view of above facts, the present research was designed to assess the presence of pathogenic fungi on tomato seeds and the possibility of controlling these pathogens using botanical extracts.

\section{MATERIALS AND METHODS}

The experiment was conducted at the Seed Pathology Center (SPC) and Department of Plant Pathology, Bangladesh Agricultural University (BAU), Mymensingh. 


\section{Collection of seed samples}

Seeds of five tomato seed varieties viz. Manik, Ratan, Roma VF, Kapatakkho and Monirampuri were collected from commercial seed shops of Mymensingh sadar upazilla. The seeds were kept in brown paper bags and stored in the refrigerator at $5^{\circ} \mathrm{C}$, till the seeds were used for the subsequent studies.

\section{Seed health test}

Seed health test was done by blotter method following the rules of International Seed Testing Association (ISTA, 1996). In this method, three pieces of filter paper (Whatman no.1) were soaked in sterilized water and placed at the bottom of $9 \mathrm{~cm}$ diameter glass petridish. Four hundred seeds from each sample were taken randomly and then placed on the moist filter paper at the rate of 25 seeds per plate. The petridishes with the seeds were then incubated at $25 \pm 2^{\circ} \mathrm{C}$. Seeds produced both plumule and radical after incubation were considered as sprouted seeds. The result was expressed as percentage.

\section{Identification of seed borne fungi on tomato seeds}

Incubated seeds were observed under stereomicroscope at 16x and 25x magnification. The incidence of seed borne fungi was detected by observing their growth characters on the incubated seeds on blotter paper following keys outline by Khan (1998). Temporary slides were prepared from the fungal colony and observed under compound microscope. The fungi were identified with the help of keys suggested by Ellis (1976) and Neergaard (1979).

\section{Preparation of plant extracts}

For the investigation antifungal effect of plant extract, plant samples such as Mahogany seeds, Mehendi and Allamanda leaves were collected from Bangladesh Agricultural University campus. The collected plant parts were washed carefully in running tap water, dried and weighed by electric balance. Mahogany seed, Mehendi leaf and Allamanda leaf extracts were prepared by grinding in mortar and pastle. Then $1 \mathrm{ml}, 2 \mathrm{ml}$ and $3 \mathrm{ml}$ of distilled water were added, respectively with $1 \mathrm{gram}$ of plant material to prepare plant extracts having 1:1, 1:2 and 1:3 doses (weight/volume). The crushed materials were filtered through cheese cloth.

\section{Treatments}

A total of 10 treatments (nine botanicals and one control) were used. Those are as follows,

$$
\begin{aligned}
& \mathrm{T}_{0}=\text { Control } \\
& \mathrm{T}_{1}=\text { Mahogany @ (1:1)w/v } \\
& \mathrm{T}_{2}=\text { Mahogany @ }(1: 2) \mathrm{w} / \mathrm{v} \\
& \mathrm{T}_{3}=\text { Mahogany @ }(1: 3) \mathrm{w} / \mathrm{v} \\
& \mathrm{T}_{4}=\text { Mehendi @ }(1: 1) \mathrm{w} / \mathrm{v} \\
& \mathrm{T}_{5}=\text { Mehendi @ (1:2) w/v } \\
& \mathrm{T}_{6}=\text { Mehendi @ }(1: 3) \mathrm{w} / \mathrm{v} \\
& \mathrm{T}_{7}=\text { Allamanda @ (1:1) w/v } \\
& \mathrm{T}_{8}=\text { Allamanda @ (1:2) w/v } \\
& \mathrm{T}_{9}=\text { Allamanda @ (1:3) w/v }
\end{aligned}
$$




\section{Seed treatment with plant extracts}

Tomato seeds were treated in each dilution $(1: 1) \mathrm{w} / \mathrm{v},(1: 2) \mathrm{w} / \mathrm{v}$ and $(1: 3) \mathrm{w} / \mathrm{v}$ of each three plant extracts Mahogany, Mehendi and Allamanda. Seed samples of tomato were dipped in each extract contained one petridishes at different dilution for one hour. Then the plant extract was drained out from the petridish. The treated seeds were shade dried on blotting papers for one hour. A set of control was maintained by dipping the seeds in tap water. After incubation, germination and seed borne fungi were observed.

\section{Data analyses}

The experiment was designed under Completely Randomized Design (CRD). The recorded data on various parameters under the present study were statistically analyzed using MSTAT-C statistical-package program. The level of significance and analysis of variance along with the Least Significance Difference (LSD) were done according to Gomez and Gomez (1984).

\section{RESULT}

\section{Pathogenic incidence of seed borne fungi on tomato seeds}

Pathogenic incidences of seed borne fungi were observed in the tomato seeds during incubation period. Four species of fungi representing three genera were identified from those incubated tomato seeds and these three predominant fungal genera were identified Aspergillus sp., Fusarium oxysporum and Cladosporium sp. The spores of Aspergillus sp., micro conidia of Fusarium oxysporum and conidia of Cladosporium sp. were observed under sereiobinocular microscope $(40 \mathrm{x})$ by making slide from seed (Figure 1). The highest pathogenic incidence of Aspergillus flavus (21.70\%) and Aspergillus niger (11.10\%) were observed in the tomato seed varieties of Manik followed by Roma VF (20.00\%) and (9.90\%), in Monirumpuri $(20.00 \%)$ and $(10.10 \%)$ and others. The one of the most predominant fungal species $F$. oxysporum was recorded in the variety Monirumpuri (25.60\%) followed by Manik (23.90\%), Roma VF (22.40\%) and others. The other fungal pathogen Cladosporium sp. was found on the tomato seed varieties Ratan (17.70\%) followed by Roma VF (14.40\%), Manik (13.30\%), Kopotakkho (11.23\%) and Monirumpuri (10.80\%) (Figure 3-7).
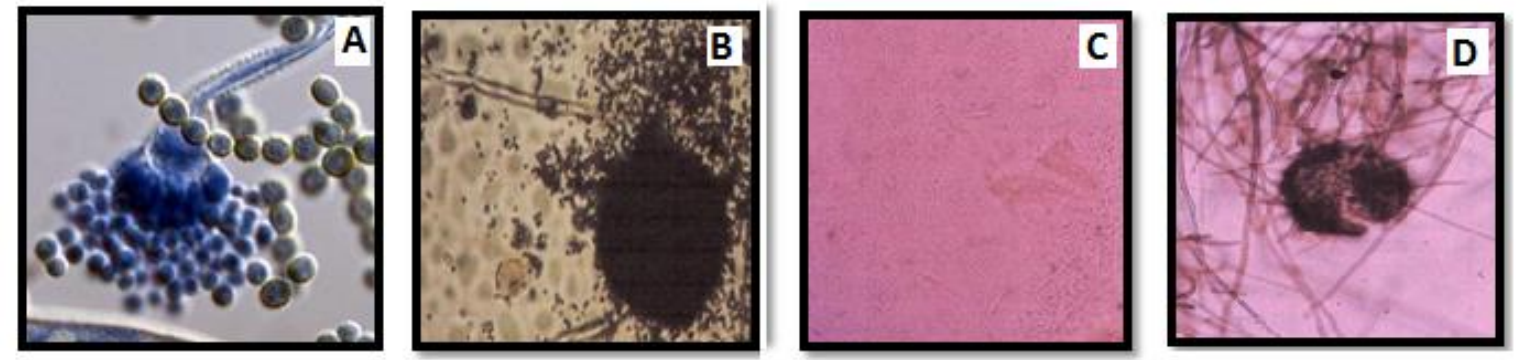

Figure 1. Different structures of seed borne pathogens observed under microscope (40x): A. Spore and sporangia of Aspergillus flavus; B. Spore and sporangia of Aspergillus niger; C. Micro conidia of Fusarium oxysporum; D. Conidia of Cladosporium sp. 


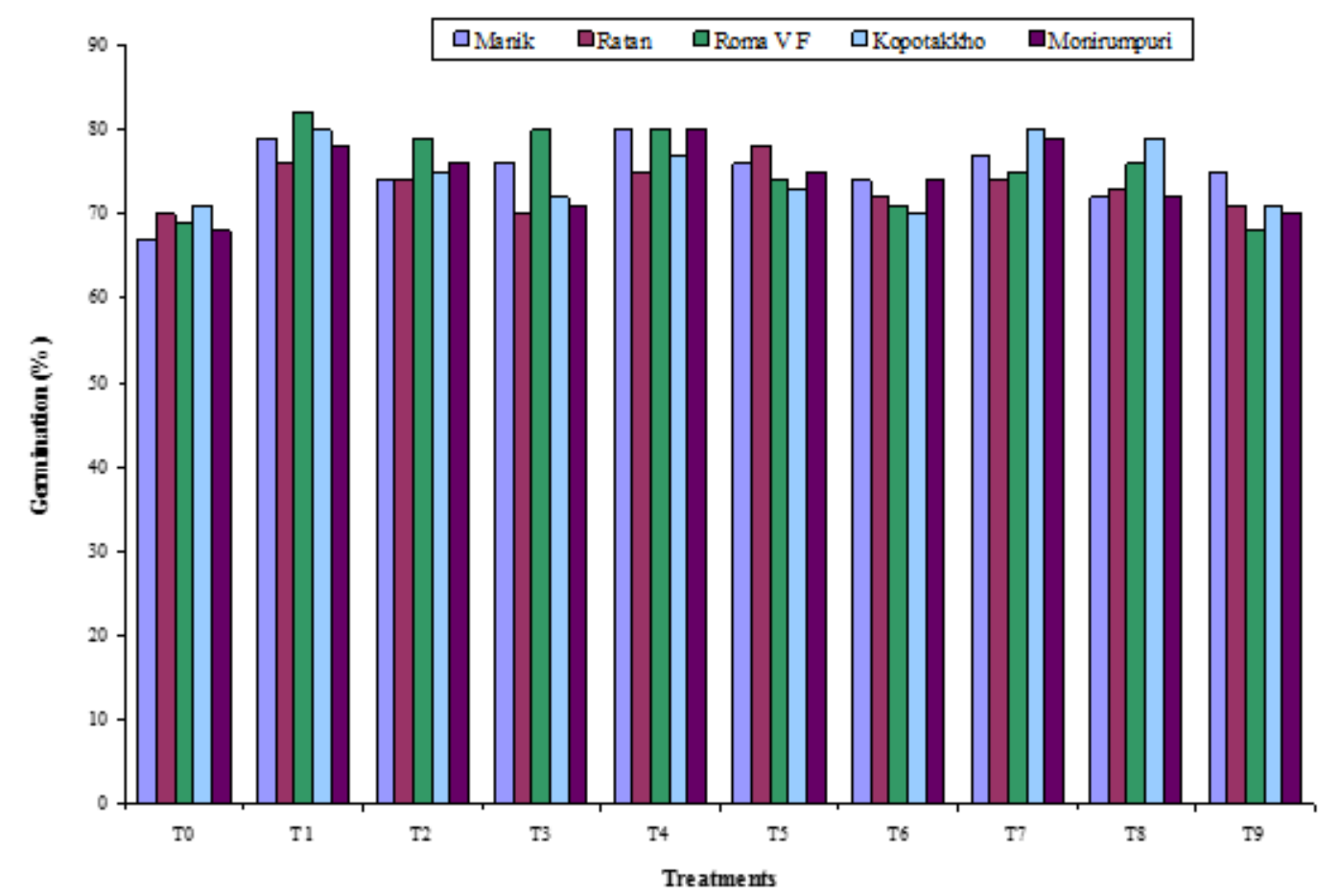

Figure 2. Percent germination of tomato seeds of different varieties with treatments

\section{Effect of seed borne fungi on germination of tomato seeds}

Collected five tomato seed samples showed significant differences in terms of seed infection by different seed-borne fungal pathogens in controlled condition and treatment. The highest germination was recorded in Kopotakkho (71\%) while the lowest in the variety Manik $(67 \%)$. The second highest germination was observed in the seed sample Ratan (70\%) followed by Monirumpuri $(68 \%)$ and Roma VF $(69 \%)$ was statistically similar.

\section{Discussion}

\section{Efficacy of plant extracts on incidence of seed borne pathogens}

Three plants extracts of Mahogany, Mehendi and Allamanda with three dilutions @ 1:1 w/v, $1: 2 \mathrm{w} / \mathrm{v}$ and $1: 3 \mathrm{w} / \mathrm{v}$ for each were used in this experiment. All the selected components showed significant effect on controlling the pathogenic incidence and increasing the seed germination. The results obtained in the present study were shown in Figure 3-7. In the tomato seed variety Manik, the best result in terms of reduction of seed borne pathogens were obtained when seed treated with $1: 1 \mathrm{w} / \mathrm{v}$ dilution of each plant extract (Mahogany, Mehendi and Allamanda). Seed treated with Mahogany extract $1: 1$ dilution yielded only $4.40 \%$ Aspergillus sp., $1.60 \%$ of Fusarium oxysporum and $1.90 \%$ Cladosporium sp. Moderate results in terms of reduction of seed borne pathogens were obtained when seed was treated with 1:2 w/v dilution of plant extract (Mahogany, Mehendi and Allamanda). The lowest result of pathogen reduction was found when seeds were treated with $1: 3 \mathrm{w} / \mathrm{v}$ dilution of plant extracts (Mahogany, Mehendi and Allamanda).

Regarding plant extract, the best result was found when seed was treated with Mahogany extract where the infections were ranged from $2.10 \%$ to $4.00 \%$ followed by Mehendi extract $3.00 \%$ to $4.20 \%$. The least result was found when seed was treated with Allamanda extract where infections were recorded from $3.50 \%$ to $5.10 \%$. 

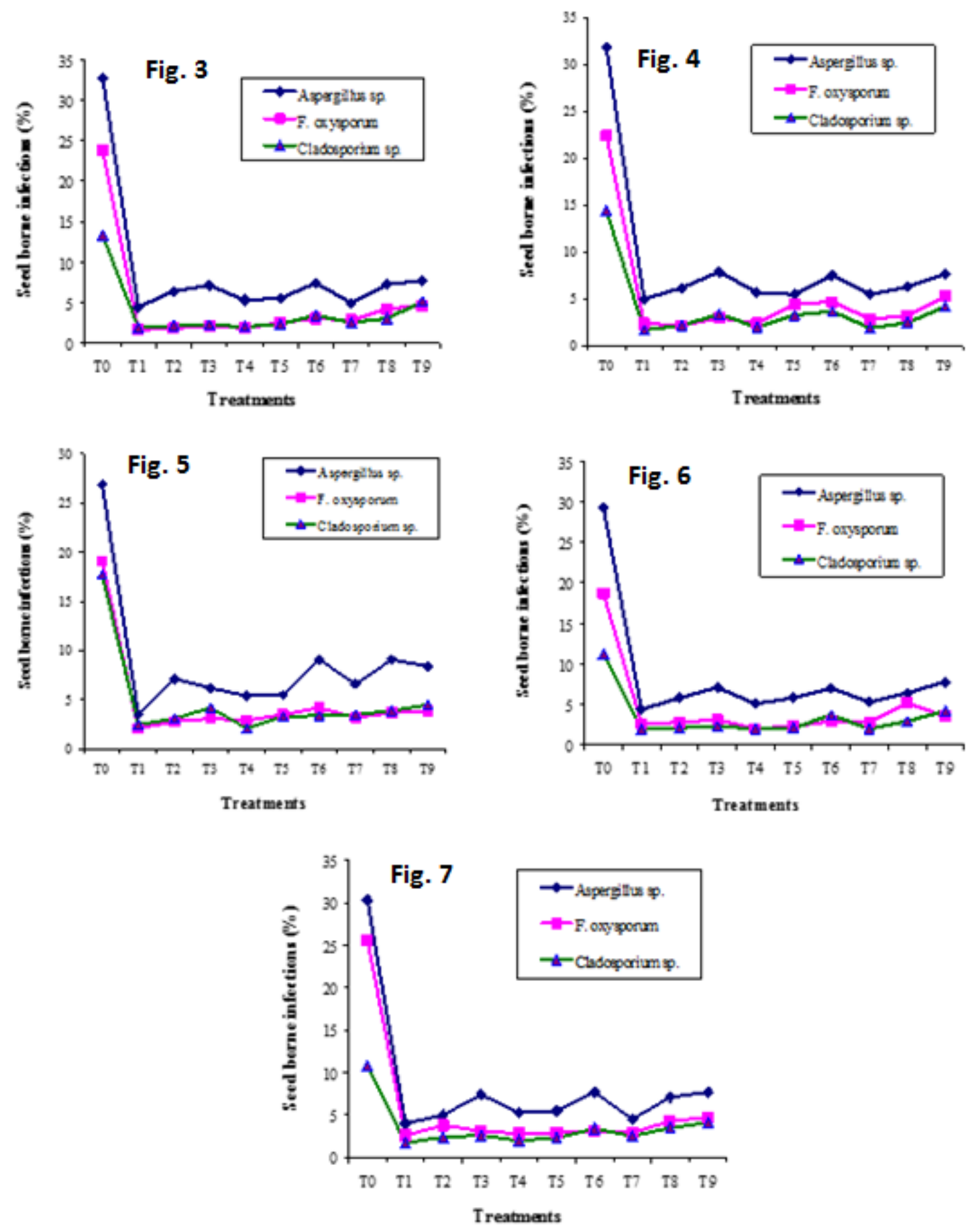

Figure 3. Effect of plant extracts on tomato seed variety Manik; Figure 4. Effect of plant extracts on tomato seed variety Ratan; Figure 5. Effect of plant extracts on tomato seed variety Ruma V F; Figure 6. Effect of plant extracts on tomato seed variety Monirumpuri; Figure 7. Effect of plant extracts on tomato seed variety Kopotakkho 
The findings of the present investigation agreed with the findings of other previous results. Islam (2012) treated the tomato seeds with Garlic, Neem and Allamonda extracts with 1:1 dilution. Among the plant extracts, garlic extract 1:1 was found the best treatment for reduction of seed borne infection. Akter (2008) reported that garlic extract @ (1:1) and chirota @ (1:2) showed best preference to reduce Collectotrihum dematium, Macrophomina Phaseolina, Cercospora sp. Aspergillers niger, Aspergiller flavus and Penicllium sp. Among them garlic clove (Allium sativum) extract was observed to be the most effective followed by allamanda, neem and marigold extract in reducing seed borne fungi. Begum and Momin (2007) successfully demonstrated the antifungal activity of plant extracts in disease control of seed borne fungal pathogen.

\section{Efficacy of plant extracts on the germination (\%) of tomato seeds}

The results of the present study showed that, almost all the treatments significantly showed positive performance in compared to control after treating the seeds with different botanicals. It is revealed from the Figure 2 that, the tomato seed variety Manik showed the lowest germination which was recorded $67 \%$ in control while in treated seeds, ranged from $72-80 \%$. The highest germination (80\%) was obtained in $\mathrm{T}_{4}$ (Mehendi extract @ 1:1 w/v) where the lowest germination (72\%) was obtained in $\mathrm{T}_{8}$ (Allamanada extract @ 1:2 w/v). In case of variety Ratan, the germination was recorded from $71-78 \%$ in treated seeds while $70 \%$ was in the control (Figure 2). The seed treated with $\mathrm{T}_{5}$ (Mehendi extract @ 1:2 w/v) showed the highest germination (78\%) while the lowest germination (71\%) was obtained from T9 (Allamonda extract @ 1:3 w/v). In case of Roma VF, the seed germination (\%) was recorded as $68-82 \%$. The highest germination (82\%) was found the seed treated with $T_{1}$ (Mahogany extract @ 1:1 w/v) followed by $T_{3}$ (Mahogany extract @ 1:3 w/v) and $\mathrm{T}_{4}$ (Mehendi extract @ 1:1 w/v). The lowest germination (\%) was found in the seed treated with T9 (Allamanda extract @ 1:3 w/v). In case of Monirumpui, germination was $71 \%$ recorded in control treatment. In treated seeds, germination was ranged from 70-80\%. The highest germination (80\%) was obtained in $\mathrm{T}_{1}$ (Mahogany extract @ 1:1 w/v) and $\mathrm{T}_{7}$ (Allamanda extract @ $1: 1 \mathrm{w} / \mathrm{v}$ ) where the lowest germination $(70 \%)$ was obtained in $\mathrm{T}_{6}$ (Mehendi extract @ 1:3 w/v). In case of the variety Kapotakkho, germination was $68 \%$ recorded in control while in treated seeds, it was ranged from $70-80 \%$. The highest germination (80\%) was obtained in $\mathrm{T}_{4}$ (Mehendi extract @ 1:1 $\mathrm{w} / \mathrm{v}$ ) where the lowest germination (70\%) was obtained in T9 (Allamanda extract @ 1:3 w/v). Several studies have demonstrated increased seed germination and vigour index in different crop after application of plant extracts. The findings of the present investigation are very much similar with the findings of other previous investigators. Howlader (2003) reported that seed treatment with Allamanda leaf extract (I:I) effectively increased germination of eggplant seeds and tremendously decreased nursery diseases. Hasan et al., (2005) stated that plant extracts increase seed germination and improves seedling vigour or development. Islam (2009) reported that garlic plant extract @ 1:1 Concentration was found most effective among garlic clove, biskathali, allamanda, tobacco, neem increasing germination percentage and controlling seed borne fungal pathogens of mustard. Hossen 2015 stated that, Garlic extract (1:1) was effective treatment for seed germination and controlling the associated seed borne fungi in chilli.

\section{CONCLUSION}

Fusarium oxysporum is reported to be one of the most predominant seed borne as well as soil borne pathogen which can cause reduction in germination by triggering root rot and wilt of tomato. Seed borne pathogen infected the seed from seedling germination to yield formation and transmitted to the seed again. Emphasis should be undertaken for further research with more representative seed samples of different varieties of tomato collected from various tomato growing areas in order to unveil the extract picture of seed borne pathogens and their best control measures by plant extracts. Incorporating Mahogany, Mehendi and Allamanda extracts in the IPM system of Bangladesh can save huge amount of foreign currency and keep the environment pollution free. 


\section{REFERENCES}

1. Akter N, 2008. Effect of plant extract in the management of seed borne fungal disease of okra. MS Thesis, Department of Plant Pathology, Bangladesh Agricultural Uniiversity, Mymensingh. pp: 36 \& 74.

2. Begum HA and A Momin, 2007. Comparison between two detection techniques of seed borne pathogen in cucurbits in Bangladesh. Pakistan Journal of Scientific and Industrial Research, 43: 244248.

3. Ellis MB, 1976. Dematiaceous Hyphomycetes. Kew, England: Commonwealth Mycological Institute.

4. Gomez KA and AA Gomez, 1984. Statistical procedure for agricultural research. 2"d Edition. John Willey and Sons, New York, pp: 640.

5. Hassan MM, SP Chowdhury, S Alam, B Hossain and MS Alam, 2005. Antifungal effects of plant extracts on seed borne fungi of wheat seed regarding seed germination, seedling health and vigour index. Pakistan Journal of Biological Science, 8: 1284-1289.

6. Hossen MT, 2015. Management of seed borne fungi in chilli. MS Thesis, Department of Plant Pathology, Bangladesh Agricultural University, Mymensingh.

7. Howlader AN, 2003. Effect of seed selection and seed treatment on the development of phomopsis blight and fruit rot of Eggplant. MS Thesis, Department of Plant Pathology, Bangladesh Agricultural University, Mymensingh, pp. 40-68.

8. Islam SME, 2012. Health and quality of tomato seeds collected from Abhoynagor Upazilla of Jessore district and their management by plant extracts. MS Thesis, Department of Plant Pathology, Bangladesh Agricultural University, Mymensingh.

9. Islam MF, 2009. Health and quality of mustard seeds collected from Fulbaria Upazilla of Mymensingh district and control of its fungi by plant extracts. MS Thesis, Department of Plant Pathology, Bangladesh Agricultural University, Mymensingh, pp. 40.

10. Islam NF and SK Borthakur, 2012. Screening of mycota associated with Aijung rice seed and their effects on seed germination and seedling vigour. Plant Pathological Quarantine, 2: 75-85.

11. ISTA (International Seed Testing Association), 1996. International Rules of Testing Association. In: Proceedings of International Seed Testing Association pp: 180.

12. Khan MQ and SI Ahmed, 1998. Seed borne microflora of vegetable seed lots in Northern areas of Pakistan. Pakistan Journal of Science and Industrial Research, 41: 47-49.

13. Neergaard P, 1979. Introduction to methods of seed-health testing. Seed Science and Technology, 7: 601-635.

14. Nwachukwu EO and CI Umechuruba, 2001. Antifungal activities of some leave extracts on seed borne fungi of African yam bean seeds. Journal of Applied and Natural Sciences, 1: 29-31.

15. Okigbo RN, 2004. A review of biological control methods for post-harvest yams (Dioscorea sp.) in storage in south eastern Nigeria. KMITL Journal of Science, 4: 207-215.

16. Singh D and SB Mathur, 2004. Location of fungal hyphae in seeds. In: Singh D, Mathur SB, editors. Histopathology of Seed-Borne Infections. Boca Ratan, FL, USA: CRC Press, pp: 101-168.

17. Yang VW and CA Clausen, 2007. Antifungal effect of essential oils on southern yellow pine. International Biodeterior Biodegrade, 59: 302-306.

18. www.growtomatoes.com, Vegetable Gardening Hydroponically: Complete Guide for the Home Gardener and Commercial Vegetable Grower: An e-book by Dr. J. Benton Jones of University of Georgia, USA.

19. www.factfish.com, Bangladesh: Tomatoes, production quantity (tons) collected from FAOSTAT (The statistics division of Food and Agriculture Organization of the United Nations). 